\title{
Optimal grazing management to achieve high yields and utilisation of dryland lucerne
}

\author{
D.J. MOOT, S.M. BENNETT, A.M. MILLS and M.C. SMITH \\ Field Research Centre, Faculty of Agriculture \& Life Sciences, \\ PO Box 85084, Lincoln University 7647, New Zealand \\ derrick.moot@lincoln.ac.nz
}

\begin{abstract}
The pre- and post-grazing dry matter yields from six individual paddocks in a grazed lucerne rotation were compared at Ashley Dene, Lincoln University, over 5 years. The mean annual yield was $\sim 12000 \mathrm{~kg}$ $\mathrm{DM} / \mathrm{ha}$ and unaffected by the rotation order in which paddocks were first grazed in spring. On an annual basis the post-graze residual was about $1000 \mathrm{~kg}$ $\mathrm{DM} /$ ha lower from Paddock 1 than Paddock 6. First grazing usually occurred with ewes and lambs in the third week of September when the pre-grazing height was $15-25 \mathrm{~cm}$. Rapid spring growth of lucerne meant Paddock 6 was sometimes over $40 \mathrm{~cm}$ tall with a pregrazing mass of $4000 \mathrm{~kg} \mathrm{DM} / \mathrm{ha}$ upon first entry 4-5 weeks later. The grazing interval between the first and second rotation in spring was between 29 and 36 days. There was an average $1800 \mathrm{~kg} \mathrm{DM} /$ ha more on offer in Paddock 6 than Paddock 1 in the first rotation. On average, the ewes and lambs consumed $\sim 2100 \mathrm{~kg} \mathrm{DM} /$ ha at $\sim 75 \%$ utilisation from each paddock in the first rotation. Weaned lambs offered similar pre-grazing yields consumed less herbage $(\sim 1700 \mathrm{~kg} \mathrm{DM} / \mathrm{ha})$ at $\sim 60 \%$ utilisation. A lower pre-graze target for lambs (2000-2500 $\mathrm{kg} \mathrm{DM} / \mathrm{ha})$ is therefore recommended, particularly if there is no other class of stock available to consume the residual. This may require a quicker rotation with weaned lambs than the 34 days averaged in this study. For ewes and lambs the target of $~ 3000$ $\mathrm{kg} \mathrm{DM} / \mathrm{ha}(\sim 30-35 \mathrm{~cm}$ pre-grazing height) used for this study seemed appropriate rather than a fixed number of days or particular phenological stage.
\end{abstract}

Keywords: alfalfa, lucerne, Medicago sativa L., rotational grazing, stock class, utilisation

\section{Introduction}

The use of lucerne (Medicago sativa) has increased farm productivity and created resilience for dryland farm systems which experience highly variable spring/ summer rainfall (Moot 2014). Lucerne can produce large quantities of high quality feed, particularly in spring (Moot et al. 2003). This feed supply has allowed successful dryland farm systems to be developed in areas of low rainfall on the east coast of New Zealand (Avery et al. 2008). On these farms, the aim is to maximise livestock growth rates in spring and early summer so stock can be finished or sold store at heavier weights before summer dry conditions restrict lucerne growth (Anderson et al. 2014).

As the benefits of utilising lucerne have become more widely understood its use on farm has increased, with $\sim 150000$ ha now established (Monk et al. 2016). However, inappropriate grazing management is often implicated in reduced lucerne stand persistence (Cosgrove \& White 1990) and this can affect animal growth rates. A critical factor for animal production is the amount of dry matter (DM) actually consumed by grazing animals and the efficiency with which it is consumed, or utilised (Thomson 1977). Historically, lucerne utilisation was matched with phenological stage of development of plants, with recommendations of an initial grazing at $10 \%$ flowering (Douglas 1986). However, flowering time is strongly related to photoperiod in New Zealand and grazing recommendations are now based on height or yield (Moot et al. 2003). For lucerne, the fraction of palatable and unpalatable herbage also changes as the crop increases in height and yield (Brown \& Moot 2004). The palatable fraction of the herbage is that which stock readily consume, including the leaves and soft upper stem. The unpalatable fraction is the lignified stem that remains in the paddock post-grazing. This means the time of grazing is a key determinant of the quality of available feed on offer. Over time the utilisation by livestock of total DM decreases with herbage accumulation, as a result of an increase in the unpalatable component, and this may also be affected by the class of stock grazing. A decision for farmers is therefore how to balance the trade-off between the quality and quantity of a lucerne stand as it grows.

Optimal grazing management of lucerne requires understanding of the growth and development of the crop across all seasons (Moot et al. 2003). A six paddock grazing rotation is recommended for ideal management, as it allows a sufficient number of days for lucerne regrowth while also keeping the grazing intervals short enough so that soft leafy stem is always on offer. As lucerne regrows, new shoots develop from the base of the plant, with the leaves growing from the top of each stem. The time between each grazing in a six paddock rotation allows these new stems a chance to regrow. A challenge in a six paddock rotation is to 
maximise the DM production and utilisation off every paddock. For example, it is recommended to commence a grazing rotation when the lucerne in the first paddock is $\sim 20 \mathrm{~cm}$ tall. This ensures the lucerne in the sixth paddock in the rotation is not over mature with a high proportion of lignified stem upon entry 4-5 weeks later (Moot et al. 2003). The difference in time of first grazing may then have implications for production and intake of the forage grown across paddocks. Therefore, the primary objective of the research reported in this experiment was to quantify the DM production and utilisation by sheep of individual lucerne paddocks within a six paddock rotation. The data were generated from a 5 year grazing experiment at Ashley Dene, the Lincoln University dryland research farm. Ewes and lambs were initially grazed in spring, followed by weaned lambs and hoggets or ewes in autumn. The aim was to use these data to refine grazing management recommendations for different seasons and classes of sheep that graze lucerne in a dryland system.

\section{Methods}

\section{Experimental}

This experiment was located in paddock $\mathrm{H} 7$ at Ashley Dene Research Farm, Home Block, Canterbury, New Zealand $\left(43^{\circ} 65^{\prime} \mathrm{S}, 172^{\circ} 32 \mathrm{E}, 35 \mathrm{~m}\right.$ a.s.1.). The soil is a mix of Lowcliffe moderately deep and Lowcliffe stony soils, both of which are poorly drained (McLenaghen \& Webb 2012). The soil surface layer (0.6-1.1 m) of sandy gravels covers a stony $\sim 1.7 \mathrm{~m}$ layer below which clay is present. The total water holding capacity is around 140 $\mathrm{mm} / \mathrm{m}$ of soil for the Lowcliffe moderately deep soil and approximately $70 \mathrm{~mm} / \mathrm{m}$ for the Lowcliffe stony soil.

The experimental site was sown in 'Grasslands Moata' (Lolium multiflorum) in 2007/2008. This was grazed then ploughed, before the paddock was rotocrumbled, harrowed and rolled before sowing. In early November 2008 lucerne was sown with three runs of an Øyjoord single cone seeder per plot. There were 28 plots within each paddock, each of $6.3 \times 24.5 \mathrm{~m}$, which represented four replicates of seven different lucerne cultivars/breeding lines. These were 'Kaituna', 'Rhino', 'Runner II', 'Stamina 5', 'AgResearch (grazing tolerant)', 'AgResearch (high preference)' and 'Stamina 6GT'. Further experimental details are reported in Moot et al. (2016).

The entire experimental area covered 2.6 ha. Within this, there were six paddocks of 0.43 ha $(48 \mathrm{~m} \mathrm{x} 89$ $\mathrm{m})$ which were used for a conventional six paddock grazing rotation (Moot et al. 2003). There were a total of 168 plots (6 paddocks x 4 replicates x 7 cultivars) but for the purposes of this experiment no cultivar comparisons are made.

\section{Livestock and grazing management}

The livestock that grazed this experiment were ewes and lambs from Lincoln University's Coopworth stud flock at Ashley Dene. At the beginning of the experiment, ewes with twin lambs at foot were assigned to the treatments at a stocking rate of $\sim 14$ ewes/ha. Ideally, the time of the first spring grazing was based on lucerne height $(15-20 \mathrm{~cm})$. The actual start was determined by the availability of stock at lambing. In practice, grazing began between 15-20 September each year. Ewes and lambs remained on the plots until weaning, when all lambs over $34 \mathrm{~kg}$ liveweight were drafted for slaughter. If sufficient feed was available, the remaining weaned lambs were returned to the plots until reduced feed supply necessitated resulted in destocking. When necessary, supplementary stock were brought in to replace drafted animals to ensure feed supply and animal demand were aligned. From mid-summer to autumn the lucerne was left ungrazed at least once until a minimum of $50 \%$ of stems were flowering to allow the replenishment of root reserves (Moot et al. 2003). Following autumn rains, lucerne regrowth was grazed with hoggets, before a final clean-up graze, usually with ewes, when frosts stopped lucerne growth in late May/ early June.

For each year the first paddock grazed was designated as Paddock 1 and then others numbered sequentially based on the order of first entry in spring. Paddocks 1-6 were set for each year but were not necessarily the same across years. The decision of grazing order for the first spring rotation each year was based on available herbage in each of the six paddocks. Within grazing periods, stock were shifted every 6-8 days depending on how long it took them to achieve the desired grazing residual. This residual was determined by the maturity of the lucerne, but it was intended that a high proportion, if not all the leaf matter and vegetative stem were consumed. A put and take stocking policy was used to alter the stocking rate as feed supply dictated. The desired target entry for each paddock was $\sim 3000 \mathrm{~kg}$ $\mathrm{DM} / \mathrm{ha}$. No topping of the lucerne occurred.

\section{Measurements}

Lucerne height $(\mathrm{cm})$ was measured pre- and postgrazing for each plot using an automated sward stick. The height measurements were calibrated for DM by taking a series of quadrat cuts from the lucerne. A $0.2 \mathrm{~m}^{2}$ quadrat was used to determine the relationship between height and DM. The shoots were cut using a pair of hand shears above crown height, so only regrowth material was included. The samples were dried in a forced-air draft oven at $65{ }^{\circ} \mathrm{C}$ for a minimum of 48 hours to a constant weight. The values obtained from the DM cuts and the height measurements were used to create calibrations to convert pre- and post-grazing lucerne 
heights to DM yield estimates. Due to workload constraints not all calibration data were collected in every rotation nor from every cultivar, plot or paddock within the experiment (Moot et al. 2016).

\section{Statistical analysis}

All statistical analyses were conducted using Genstat (v16, VSN International Ltd). Data for individual paddocks were subjected to a one-way analysis of variance (ANOVA) with paddock as the main effects factor. For the analysis of annual yields, year was used which meant there were five replicates. Fisher's protected LSD was used to identify any differences among paddocks at $\alpha=0.05$ level where the ANOVA identified a significant effect $(\mathrm{P}<0.05)$. The height against DM data were analysed by fitting linear regressions. These are outlined fully in Moot et al. (2016). Where there were missing values they were replaced with the treatment mean to balance designs.

\section{Results and Discussion}

Accumulated DM yield and post-graze residual data are summarised for the experimental period $(2009 / 2010-2014 / 2015)$ in Figure 1. Data were collected for most pre-grazing periods for each paddock but some post-graze data are missing. Therefore, analysis and discussion focuses on years when complete datasets were available (2010-2013). A feature of each year is the almost linear increase in DM yields in the first rotation each spring. This is caused by rapid stem elongation of expanding internodes that developed slowly during winter (Moot et al. 2003). The lucerne height at entering the first paddock for grazing therefore has consequences for the yield and utilisation of all the

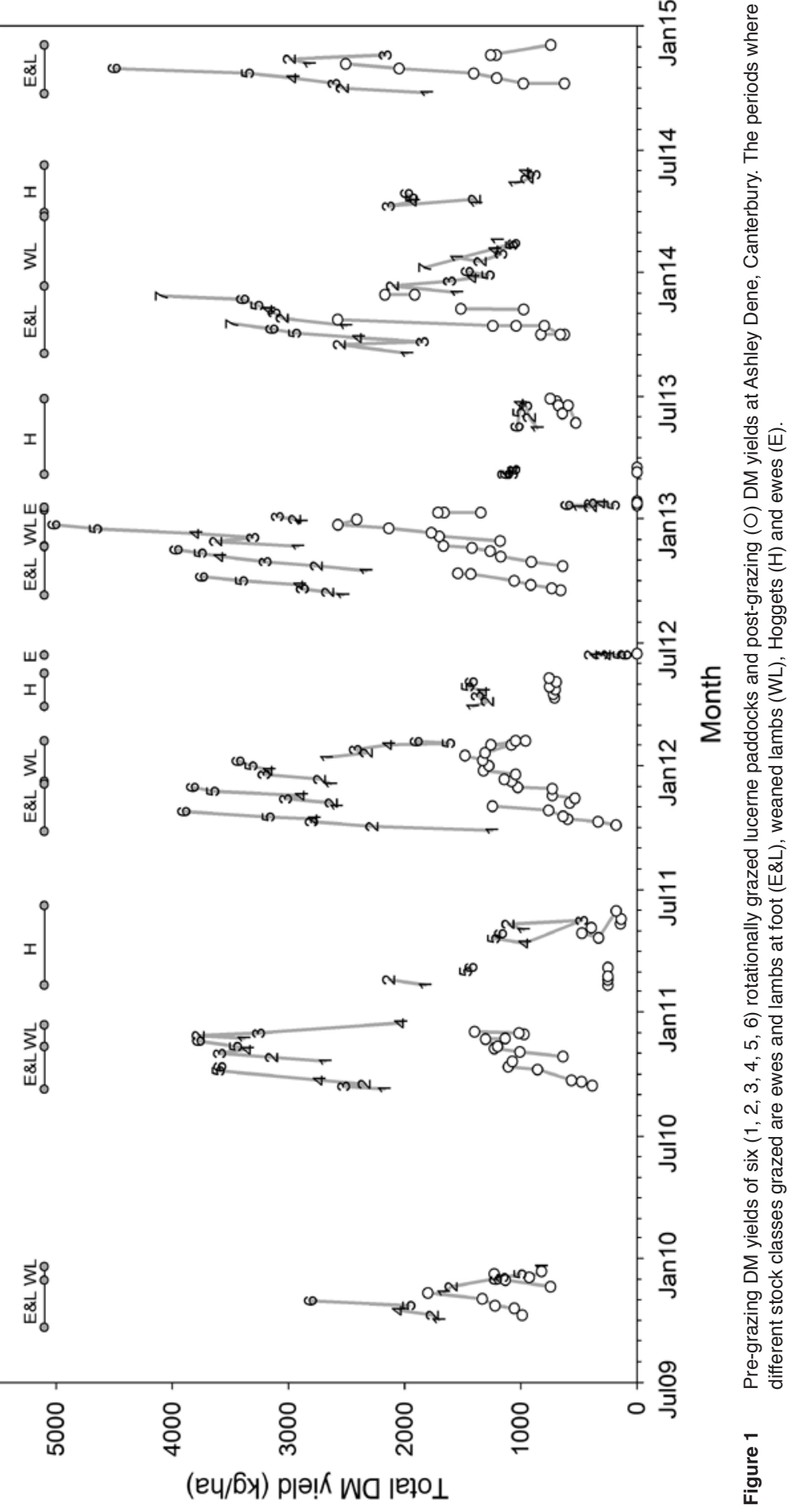

following paddocks. For example, the first paddock grazed in spring 2011 was $15.3 \mathrm{~cm}$ tall and contained $1250 \mathrm{~kg} \mathrm{DM} / \mathrm{ha}$ when ewes and lambs entered on $27^{\text {th }}$ September. They consumed $85 \%$ of the feed on offer, 
leaving a residual of $\sim 200 \mathrm{~kg} \mathrm{DM} / \mathrm{ha}$ when they were shifted to the second paddock on $3^{\text {rd }}$ of October. During that first week of grazing the lucerne canopy in Paddock 2 had doubled in height to $28 \mathrm{~cm}$ and the pre-graze yield was $2300 \mathrm{~kg} \mathrm{DM} / \mathrm{ha}$. By the time they entered Paddock 6 on $25^{\text {th }}$ October the canopy was $48 \mathrm{~cm}$ tall and the pre-graze herbage $>4000 \mathrm{~kg} \mathrm{DM} / \mathrm{ha}$. As a result of the additional height, the lucerne stem had become more lignified and the post-grazing residual increased to $1300 \mathrm{~kg} \mathrm{DM} / \mathrm{ha}$ meaning utilisation was $68 \%$.

The ewes and lambs then returned to Paddock 1, 30 days after they had left, and it had regrown to $\sim 30 \mathrm{~cm}$ or $2600 \mathrm{~kg} \mathrm{DM} / \mathrm{ha}$. The utilisation of this paddock was $78 \%$ leaving a post-graze residual of $\sim 600 \mathrm{~kg} \mathrm{DM} / \mathrm{ha}$. By the time they re-entered Paddock 6 for the second time it had regrown to $3800 \mathrm{~kg} \mathrm{DM} / \mathrm{ha}$ and the residual was again higher at $1100 \mathrm{~kg} \mathrm{DM} / \mathrm{ha}$, which meant utilisation was $72 \%$. At the end of this rotation the lambs were weaned and they re-entered Paddock 1 to begin the third grazing rotation on $5^{\text {th }}$ December when it had $\sim 2600 \mathrm{~kg} \mathrm{DM} / \mathrm{ha}$ available. They left a postgrazing residual of $1150 \mathrm{~kg} \mathrm{DM} / \mathrm{ha}$ with a utilisation of $57 \%$. By Paddock 6 the pre-graze yield was $3400 \mathrm{~kg}$ $\mathrm{DM} /$ ha on the $8^{\text {th }}$ January and they utilised $57 \%$ of this feed. The fourth rotation started to show a reduction in herbage on offer as the summer dry conditions developed. This meant Paddock 1 had the highest yield on entry of $2600 \mathrm{~kg} \mathrm{DM} / \mathrm{ha}$ on the $13^{\text {th }}$ January compared with $1900 \mathrm{~kg} \mathrm{DM} / \mathrm{ha}$ for Paddock 6 on $1^{\text {st }}$ February. The utilisation of herbage for all paddocks in this $4^{\text {th }}$ rotation was $36-55 \%$. This reflects the reduction in leaf material and palatable stem being produced as water stress affected plant regrowth (Brown \& Tanner 1983). Stock were then removed from the paddocks for the month of March before hoggets consumed the $\sim 1400 \mathrm{~kg} \mathrm{DM} / \mathrm{ha}$ that had accumulated in each paddock in April. The final clean-up graze occurred with ewes in most years and was completed by the $13^{\text {th }}$ of June.
This pattern of grazing was consistent across all years with a difference of $\sim 1800 \mathrm{~kg} \mathrm{DM} /$ ha available for consumption between the first and sixth paddock grazed. The time of first entry to Paddock 1 differed based on the availability of stock but commenced when lucerne was $15-25 \mathrm{~cm}$ tall in any given year. In most cases the ewes and lambs began grazing 2 weeks after lambing by the third week of September. This is considerably earlier than previous recommendations, based on time of flowering, which suggested October grazing at the earliest (White \& Lucas 1990). Data from the current experiment confirm there was no need to wait for any sign of reproductive development before grazing. Furthermore, to control the regrowth in later rotations and maximise utilisation, it seems appropriate to commence grazing Paddock 1 when it is $\sim 15 \mathrm{~cm}$ tall. Later entry into this first paddock had ongoing consequences to those to be grazed later in the rotation. This recommendation for earlier spring grazing should aid sheep systems where feed is often in short supply.

The utilisation of herbage changed with stock class (Table 1). The ewes and lambs averaged $65-77 \%$ utilisation compared with $49-71 \%$ for the weaned lambs. In many individual rotations the residual for weaned lambs was left deliberately higher to maximise their intake on high quality herbage (Figure 1). The lower utilisation in the 2012/2013 season was likely a result of the higher mean pre-grazing yield $(3100 \mathrm{~kg}$ $\mathrm{DM} / \mathrm{ha})$. These results are consistent with previous reports (Jagusch et al. 1971) that indicate young weaned lambs will consume the stem apex of a lucerne plant first, followed by side leaves. This selective grazing of the palatable fraction is the main reason for high lamb growth rates reported on lucerne. Douglas (1986) reported daily liveweight gains of lambs grazing spring lucerne in excess of $300 \mathrm{~g} / \mathrm{hd} / \mathrm{d}$. In this experimental context, we did not have another class of stock following, but on-farm cattle or ewes following

Table 1 Average (Avg) pre-graze dry matter yield ( $\mathrm{kg} \mathrm{DM} / \mathrm{ha}$ ), average DM consumed and average utilisation across all grazing events (paddock entries) for three stock classes at Ashley Dene, Canterbury.

\begin{tabular}{lcccc}
\hline Stock class & Year & Avg pre-graze DM yield (kg DM/ha) & Avg DM consumed (kg DM/ha) & Avg utilisation (\%) \\
\hline \multirow{2}{*}{ Ewes \& lambs } & $2010 / 2011$ & 2973 & 2120 & 72 \\
& $2011 / 2012$ & 2897 & 2195 & 77 \\
& $2012 / 2013$ & 3142 & 2025 & 65 \\
\hline \multirow{2}{*}{ Weaned lambs } & $2010 / 2011$ & 2820 & 2031 & 71 \\
& $2011 / 2012$ & 2629 & 1493 & 54 \\
& $2012 / 2013$ & 3582 & 1751 & 49 \\
\hline \multirow{2}{*}{ Hoggets } & $2010 / 2011$ & 1235 & 967 & 76 \\
& $2011 / 2012$ & 1378 & 656 & 47 \\
& $2012 / 2013$ & 964 & 319 & 33 \\
\hline
\end{tabular}


the lambs would have had access to around $1000 \mathrm{~kg} \mathrm{DM} / \mathrm{ha}$ left by the weaned lambs.

The hoggets were frequently left to graze the dried regrowth stem in mid-summer so their utilisation was $33-76 \%$ depending on the quality and amount of herbage on offer. The $76 \%$ occurred in 2010/2011 when low rainfall meant an early summer dry and the destocking of weaned lambs occurred by the $20^{\text {th }}$ December. Hoggets were not returned until $10^{\text {th }}$ February when there was $2000 \mathrm{~kg} \mathrm{DM} / \mathrm{ha}$ on offer. In contrast, the hoggets were used for the final cleanup graze in 2012/2013 when they only consumed $33 \%$ of the herbage on offer.

The need to maintain flexibility in lucerne grazing management is illustrated by the 2012/2013 year. In that spring Paddock 1 was $25 \mathrm{~cm}$ tall when stock were available to enter on the $25^{\text {th }}$ September. By the end of the second grazing Paddock 6 had $\sim 4000 \mathrm{~kg} \mathrm{DM} / \mathrm{ha}$ and utilisation had dropped to $58 \%$ with $1700 \mathrm{~kg} \mathrm{DM} / \mathrm{ha}$ of post-grazing residual. Rotation 3 saw further rapid growth of the lucerne that was beyond the capacity of the grazing rotation to utilise with the residual DM reaching $2600 \mathrm{~kg} \mathrm{DM} / \mathrm{ha}$. In a commercial situation Paddocks 5 and 6 could have been conserved as hay or silage. Paddock 6 had $\sim 5000 \mathrm{~kg} \mathrm{DM} / \mathrm{ha}$ upon entry on $23^{\text {rd }}$ of December and utilisation was only $50 \%$. This contrasts with the destocking required from no growth at the same time in the 2010/2011 season and highlights the variability of feed supply on east coast dryland farms associated with in season rainfall (Baars et al. 1975). This is reflected in the total annual DM yields that differed $(\mathrm{P}<0.001)$ among years. The lowest annual yield was in the 2010/2011 and 2013/2014 $(10680 \pm 445.8 \mathrm{~kg} / \mathrm{ha})$ and the highest (14 $110 \mathrm{~kg} / \mathrm{ha}$ ) in $2012 / 2013$.

The difference in pre-graze herbage in the first rotation each spring did not affect the total dry matter grown from each paddock (Table 2). When averaged across paddocks for Years 2-5 the annual pre-graze yield was $\sim 12000 \pm 546.0 \mathrm{~kg}$ $\mathrm{DM} / \mathrm{ha} / \mathrm{yr}$ and not different $(\mathrm{P}<0.537)$ from Paddock 1 to Paddock 6. The entry into Paddock 1 at a lower initial yield was compensated for by it growing more herbage in the final rotation before summer destocking each year. This suggests that
Table 2 Accumulated annual pre- and post-graze total DM yields ( $\mathrm{kg} / \mathrm{ha})$ and annual utilisation (\%) from paddocks 1 to 6 between 2009/2010 and $2014 / 2015$. Note that for $2009 / 2010$ and $2014 / 2015$ data were only recorded during the lactation phase (partial year and in 2009/2010 paddocks 3 and 6 were grazed twice but yields were only available for one of the grazing events. Pre-graze analysis used data from Years 2-5, post-graze and utilisation analysis used data from Years 2-4.

\begin{tabular}{|c|c|c|c|c|}
\hline Year & $\begin{array}{l}\text { Paddock } \\
\text { sequence }\end{array}$ & $\begin{array}{c}\text { Accumulated } \\
\text { pre-graze } \\
\text { yield (kg/ha) }\end{array}$ & $\begin{array}{c}\text { Accumulated } \\
\text { post-graze } \\
\text { yield (kg/ha) }\end{array}$ & $\begin{array}{c}\text { Annual } \\
\text { utilisation } \\
(\%)\end{array}$ \\
\hline \multirow{6}{*}{$\begin{array}{l}\text { 2009/2010 } \\
\text { spring }\end{array}$} & 1 & 4185 & 1730 & 59 \\
\hline & 2 & 3359 & 2186 & 35 \\
\hline & 3 & 1215 & 926 & 24 \\
\hline & 4 & 3812 & 2619 & 31 \\
\hline & 5 & 3209 & 2448 & 24 \\
\hline & 6 & 1962 & 1330 & 32 \\
\hline \multirow[t]{6}{*}{$2010 / 2011$} & 1 & 9666 & 3364 & 65 \\
\hline & 2 & 10896 & 2384 & 78 \\
\hline & 3 & 10420 & 2882 & 72 \\
\hline & 4 & 11977 & 2634 & 78 \\
\hline & 5 & 10680 & 2132 & 80 \\
\hline & 6 & 8533 & 2596 & 70 \\
\hline \multirow[t]{6}{*}{ 2011/2012 } & 1 & 10902 & 3912 & 63 \\
\hline & 2 & 11650 & 3709 & 67 \\
\hline & 3 & 13120 & 4602 & 64 \\
\hline & 4 & 14569 & 4558 & 68 \\
\hline & 5 & 13359 & 4849 & 63 \\
\hline & 6 & 12526 & 4346 & 65 \\
\hline \multirow[t]{6}{*}{$2012 / 2013$} & 1 & 12642 & 2319 & 81 \\
\hline & 2 & 14101 & 2850 & 79 \\
\hline & 3 & 15472 & 3206 & 78 \\
\hline & 4 & 14888 & 2086 & 86 \\
\hline & 5 & 14454 & 1642 & 88 \\
\hline & 6 & 13121 & 1294 & 90 \\
\hline \multirow[t]{7}{*}{$2013 / 2014$} & 1 & 11659 & $\mathrm{nd}^{1}$ & - \\
\hline & 2 & 10935 & nd & - \\
\hline & 3 & 11987 & nd & - \\
\hline & 4 & 8961 & nd & - \\
\hline & 5 & 11059 & nd & - \\
\hline & 6 & 11390 & nd & - \\
\hline & 7 & 9148 & nd & - \\
\hline \multirow{6}{*}{$\begin{array}{l}2014 / 2015 \\
\text { spring }\end{array}$} & 1 & 5525 & 2235 & 60 \\
\hline & 2 & 2960 & 1404 & 53 \\
\hline & 3 & 4495 & 2505 & 44 \\
\hline & 4 & 4624 & 1833 & 60 \\
\hline & 5 & 4770 & 1946 & 59 \\
\hline & 6 & 3349 & 2046 & 39 \\
\hline \multirow[t]{6}{*}{ Paddock Means } & 1 & 11170 & $2446_{c}$ & 78 \\
\hline & 2 & 12181 & $2661 \mathrm{bc}$ & 78 \\
\hline & 3 & 12152 & $3351_{a b}$ & 72 \\
\hline & 4 & 11781 & $3016_{\mathrm{abc}}$ & 75 \\
\hline & 5 & 12318 & $3527 \mathrm{a}$ & 72 \\
\hline & 6 & 12615 & $3453_{a}^{a}$ & 73 \\
\hline \multicolumn{2}{|c|}{ Paddock Grand mean } & 12036 & 3076 & 75 \\
\hline \multicolumn{2}{|l|}{ SEM } & 546.0 & 221.2 & 2.4 \\
\hline \multicolumn{2}{|l|}{ Significance } & 0.537 & 0.028 & 0.248 \\
\hline
\end{tabular}

${ }^{1}$ no data. Means followed by the same letter are not different at the $a=0.05$ level. 
the growth of lucerne was affected by the available soil moisture in each paddock and because this was the same across paddocks (Sim 2014) the yield of lucerne was too. The rotational grazing of lucerne also provided an indicator of available feed as each grazing season progressed. When recovery was slow in the rotation it provided a visual indicator that soil moisture was limiting growth. The time of this differed among years and is highlighted by the declining yields on entry to successive paddocks in summer (Figure 1). From a management perspective the regrowth rotations offered an early warning of when growth was slowing, which informed stock policy decisions.

The number of days between the first and second grazing rotation was also flexible (29.7 to $35.0 \pm 1.2)$ and dependent $(\mathrm{P}<0.009)$ on year (Table 3$)$. The grazing duration averaged $6.2 \pm 0.51$ days and was not different $(\mathrm{P}=0.457)$ amongst rotations. The longest duration of grazing was 10 days to ensure stock were removed before any new shoots had emerged. The need to shift stock was based on their consumption of the palatable fraction of the herbage on offer. This was consistently $\sim 2100 \mathrm{~kg} \mathrm{DM} / \mathrm{ha}$ for the ewes and lambs (Table 1) regardless of the herbage yield on offer on entry, which was consistent with the DM utilisation figures reported previously (Brown \& Moot 2004). Thus, yields greater than this represent the unpalatable fraction. Given the weaned lambs consumed a lower fraction of the herbage on offer, a lower yield on entry $(2000-2500 \mathrm{~kg}$ $\mathrm{DM} / \mathrm{ha}$ ) for this class of stock is recommended. This may increase their utilisation if there is no other stock class available to clean-up after them. For post-grazing, Paddocks 5 and 6 had a higher $(\mathrm{P}<0.028)$ mean annual residual (Table 2) which reflects the excessive pre-graze yields, particularly in 2012/2013 (Figure 1), compared with Paddock 1.

Table 3 Days to first return to each paddock in spring of each year (2010/2011, 2011/2012, 2012/2013 and 2013/2014) and return duration (days) by year.

\begin{tabular}{lccc}
\hline Paddock & $\begin{array}{c}\text { Return interval } \\
\text { (paddock) }\end{array}$ & Year & $\begin{array}{c}\text { Return } \\
\text { duration (d) }\end{array}$ \\
\hline 1 & 35.3 & $2009 / 2010$ & - \\
2 & 33.0 & $2010 / 2011$ & $35.0_{\mathrm{a}}$ \\
3 & 33.5 & $2011 / 2012$ & $29 . \mathrm{b}_{\mathrm{b}}$ \\
4 & 34.0 & $2012 / 2013$ & $34.3_{\mathrm{a}}$ \\
5 & 34.0 & $2013 / 2014$ & $35.8 \mathrm{a}$ \\
6 & 32.5 & $2014 / 2015$ & - \\
\hline Grand Mean & 33.7 & & 33.7 \\
SEM & 1.43 & & 1.17 \\
Significance & 0.812 & & 0.009 \\
\hline
\end{tabular}

Note: Means followed by the same letter are not different at the $\mathrm{a}=0.05$ level.

\section{Conclusions}

This experiment showed annual lucerne yield was unaffected by the order in which paddocks were first grazed in spring over the 5 year study. Grazing should commence at the start of spring when the first stand reaches a height of $\sim 15 \mathrm{~cm}$ or $\sim 1500 \mathrm{~kg} \mathrm{DM} / \mathrm{ha}$. Ewes and lambs will consume almost all of the available feed in this paddock and can then be moved on to other paddocks which are growing ahead of them. In spring a pre-graze entry target of $2500-3000 \mathrm{~kg} \mathrm{DM} / \mathrm{ha}(\sim 30 \mathrm{~cm})$ seemed appropriate for 30-36 day rotations with ewes and lambs. Post-weaning a lower entry level of 2000$2500 \mathrm{~kg} \mathrm{DM} / \mathrm{ha}$ is recommended to prioritise liveweight gain of lambs. A six paddock grazing rotation is important to manage and utilise lucerne. The number of days provided between grazing events will ensure new shoots develop to their full potential and stand yield is not limited, while also maximising livestock utilisation as they consume highly palatable leaf and stem. The grazing interval should be based on the accumulation of feed ahead of stock to maintain the desired quality of feed on entry. Flexibility is required in tactical decisions such as when to conserve feed, grazing intensity and grazing duration. These can be assisted by visual assessment or measurement of the regrowth ahead of stock which is largely dependent on in season rainfall.

\section{ACKNOWLEDGEMENTS}

This work was undertaken as part of Phase II of the Pastoral 21 Programme, funded by the Ministry for Business wInnovation \& Employment, DairyNZ, Beef + Lamb New Zealand and Fonterra. Additional financial support was provided by Mr Roland Stead.

\section{REFERENCES}

Anderson, D.; Anderson L.; Moot, D.J.; Ogle, G.I. 2014. Integrating lucerne (Medicago sativa L.) into a high country merino system. Proceedings of the New Zealand Grassland Association 76: 29-34.

Avery, D.; Avery F.; Ogle, G.I.; Wills, B.J.; Moot, D.J. 2008. Adapting farm systems into a drier future. Proceedings of the New Zealand Grassland Association 70: 13-18.

Baars, J.A.; Radcliffe, J.E.; Brunswick, L. 1975. Seasonal distribution of pasture production in New Zealand VI. Wairakei, pasture and lucerne production. New Zealand Journal of Experimental Agriculture 3: 253-258.

Brown, H.E.; Moot, D.J. 2004. Quality and quantity of chicory, lucerne and red clover production under irrigation. Proceedings of the New Zealand Grassland Association 66: 257-264.

Brown, P.W.; Tanner, C.B. 1983. Alfalfa stem and leaf growth during water stress. Agronomy Journal 75: 799-805. 
Cosgrove, G.P.; White, J.G.H. 1990. Lucerne grazing management 1 . Effect of grazing duration on herbage accumulation. New Zealand Journal of Agricultural Research 33: 615-620.

Douglas, J.A. 1986. The production and utilization of lucerne in New Zealand. Grass and Forage Science 41: 81-128.

Jagusch, K.T.; Mitchell, R.M.; McConnell, G.R.; Fennessy P.F.; Woodlock, M.R.; Jay, N.P.W. 1971. Nutrition of the young growing lamb: studies at Lincoln College. Proceedings of the New Zealand Society of Animal Production 31: 121-128.

McLenaghen, R.; Webb, T. 2012. Soil properties and fertility of Ashley Dene: the challenge. pp. 17-22. In: Ashley Dene Lincoln University Farm - the first 100 years. Eds. Lucas, D.; Gow, N.; Nicol, A. Lincoln University, Canterbury.

Monk, S.; Moot, D.J.; Belgrave, B.; Rolston, M.P.; Caradus, J.R. 2016. Availability of seed for hill country adapted forage legumes. Hill Country Symposium. Grassland Research and Practice Series 16: 257-268.

Moot, D.J. 2014. A review of recent research and extension on dryland lucerne in New Zealand. Proceedings of the New Zealand Society of Animal Production 74: 86-93.
Moot, D.J.; Brown, H.E.; Teixeira, E.I.; Pollock, K.M. 2003. Crop growth and development affect seasonal priorities for lucerne management. Legumes for Dryland Pastures. Grassland Research and Practice Series 11: 201-208.

Mills,A.M.; Smith, M.C.; Moot, D.J. 2016. Relationships between dry matter yield and height of rotationally grazed dryland lucerne. Journal of New Zealand Grasslands 78: 185-196.

Sim, R.E. 2014. Water extraction and use of seedling and established dryland lucerne crops. PhD thesis. Lincoln University.

Thomson, N.A. 1977. Factors affecting animal production: intake and utilization by ewes grazing grass/clover and lucerne pastures. Proceedings of the New Zealand Grassland Association 9: 86-97.

White, J.G.H.; Cosgrove, G.P. 1990. Lucerne grazing management 2. Effect of grazing duration on defoliation pattern by ewes. New Zealand Journal of Agricultural Research 33: 621-625.

White, J.G.H.; Lucas, W.G. 1990. Management of lucerne in the cool season. Proceedings of the New Zealand Grassland Association 52: 41-43. 
